\title{
Correlation between MVD and Two Prognostic Factors: Fuhrman Grade and Tumoral Size, in Clear Cell Renal Cell Carcinoma
}

\author{
Colaci Pablo ${ }^{1,2}$, García Marcela ${ }^{1 *}$, Errecalde Ana Lía ${ }^{1}$ and Inda Ana María ${ }^{1,3}$
}

${ }^{1}$ Cátedra de Citología, Histología y Embriología "A", Facultad de Ciencias Médicas, Universidad Nacional de La Plata, Argentina

${ }^{2}$ Hospital Zonal General de Agudos "Evita Pueblo", Berazategui, Bs. As., Argentina

${ }^{3}$ Comisión de Investigaciones Científicas (CIC), Pcia. de Buenos Aires, Argentina

\begin{abstract}
Introduction: Clear cell RCC is the most common type of RCC that occurs in adults and it has the worst prognosis among the common epithelial tumors of these organs. The CD34 is an endothelial antigen that has been used to highlight the microvessel density (MVD) as a direct marker of neoangiogenesis degree.

Objective: To establish the correlation between CD34 and other prognostic factors like Fuhrman nuclear degree and tumoral size. Material and methods: Tumour samples from 17 patients with histopathology diagnosis of clear cell RCC were examined by immunohistochemical staining for CD34. The CD34 expression was analyzed by Anova and Student Newman Multiple Comparison Test and Tuckey like post test, and finally we used a Spearman Correlation to compare with the others prognostic factors analysed and Kaplan Meier survival analysis for the disease free survival of the patients.

Results and conclusion: There is a negative correlation between the MVD and the Fuhrman nuclear grade, whereas $R=-0,46$; and $p<0,05$ and there is a positive correlation between the MVD and the maximum tumoral diameter, whereas $R=0,47$ and $p<0,05$. In conclusion, we found that a high MVD is related with a low Fuhrman nuclear grade and a high tumoral size. The possible significance of this study can be that in fact we need more than one parameter to predict the biological behavior of the clear cell CCR.
\end{abstract}

Keywords: Kidney; Clear cell CCR; MVD; Fuhrman; Tumoral size Introduction

Renal cell carcinoma (RCC) accounts for approximately 3\% of adult malignancies and $90-95 \%$ of neoplasms arising from the kidney. This disease is characterized by a lack of early warning signs, diverse clinical manifestations, and resistance to radiation and chemotherapy $[1,2]$. Between $25-30 \%$ of the patients have got metastasis at the diagnosis time and $20-30 \%$ have been recurrence after the treatment even with radical nephrectomy of primary tumours. Less than $10 \%$ of the patients with metastasis survive more than five years [3]. Clear cell RCC is the most common type of RCC that occurs in adults. It has the worst prognosis among the common epithelial tumours of the kidney [4].

Therefore, angiogenesis is an essential process in the progression of malignant tumours due to the fact that solid tumors cannot grow beyond 1-2 $\mathrm{mm}$ in diameter without neovascularization [5]. The CD34 is an endothelial antigen that has been used to highlight the microvessel density (MVD) as a direct marker of neoangiogenesis degree; however, it can react with not only "newly forming" vessels but also with normal vessels just trapped within tumour tissues [6]. The prognostic significance of the MVD in RCC is controversial; some authors affirm that it there exists a correlation between the degree of MVD and the metastasis and the survival of the patients, but other authors say that the MVD does not have correlation with any other prognostic factor [7-12].

In the present work we used the CD34 like a marker of the MVD in the human clear cell RCC, in order to establish the correlation between MVD and other prognostic factors like Fuhrman nuclear degree and tumoral size.

\section{Materials and Methods}

We used 17 samples of patients with histopathology diagnosis of clear cell RCC who were surgically treated at the "Evita Pueblo" Hospital in Berazategui, Buenos Aires province, Argentina, from 2006 to 2009 (Table 1). For this study we had the approval of the Ethics Committee from the Hospital. The patients underwent a laparoscopic surgery, based on this protocol: when the tumours were less than $4 \mathrm{~cm}$ and they were located in one of the kidney's pole, the nephrectomy was parcial; when the tumours were larger than $4 \mathrm{~cm}$ independently of their localization, the nephrectomy was radical (Table 2).

The total of samples were studied by two observers, their reports were blind to each other with the purpose of increasing the safety margin to classify them as clear cell RCC. The histological classification of tumours was based on the WHO Renal classification 2004 [13] and the TNM WHO 2009 (Table 2).

The Fuhrman nuclear grade is the manner to classify the renal carcinoma, based in the nuclear form and size and the presence of the number of nucleolus. Ours samples were divided in the 4 Furhman grade knowledge groups for the later comparison with the MVD (Table 2) (Figures 1-4).

*Corresponding author: Marcela García, Cátedra de Citología, Histología y Embriología "A", Facultad de Ciencias Médicas, Universidad Nacional de La Plata, calle 60 y 120, La Plata (1900), Buenos Aires, Argentina, Tel: 54-221-3835524 E-mail: mngarcia@med.unlp.edu.ar

Received August 01, 2012; Accepted August 29, 2012; Published August 31 2012

Citation: Pablo C, Marcela G, Lía EA, María IA (2012) Correlation between MVD and Two Prognostic Factors: Fuhrman Grade and Tumoral Size, in Clear Cell Rena Cell Carcinoma. J Cancer Sci Ther 4: 313-316. doi:10.4172/1948-5956.1000160

Copyright: () 2012 Pablo C, et al. This is an open-access article distributed under the terms of the Creative Commons Attribution License, which permits unrestricted use, distribution, and reproduction in any medium, provided the original author and source are credited. 
Citation: Pablo C, Marcela G, Lía EA, María IA (2012) Correlation between MVD and Two Prognostic Factors: Fuhrman Grade and Tumoral Size, in Clear Cell Renal Cell Carcinoma. J Cancer Sci Ther 4: 313-316. doi:10.4172/1948-5956.1000160

\section{Determination of CD34 expression}

Deparaffinised and rehydrated sections were microwaved for 10 min in buffer citrate, $\mathrm{pH}$ 6. Endogenous peroxidase was blocked for 20 min. The primary antibody against CD34 protein (Santa Cruz, Biotechnology, California, USA 1:80 dilution) was incubated for 60 min. Bound primary antibody was detected by Envision System (Dako) for $30 \mathrm{~min}$ and the reaction was developed using diaminobenzidine, and counter staining with Mayer hematoxylin. The positive control was a section of RCC that had previously shown to have a high CD34 content, by immunohistochemistry. MVD was assessed using the criteria of Weidner et al. [14]. The areas of highest vascularization were identified as regions of invasive carcinoma with the highest numbers of discrete microvessel stained for CD34. Any brown stained endothelial cell or endothelial cell cluster that was clearly separated from adjacent

\begin{tabular}{|c|c|c|}
\hline Pacient Time & Years & Gender \\
\hline 2006 & 55 & male \\
\hline 2006 & 43 & female \\
\hline 2006 & 62 & female \\
\hline 2007 & 58 & male \\
\hline 2007 & 71 & male \\
\hline 2007 & 60 & male \\
\hline 2007 & 79 & male \\
\hline 2007 & 75 & female \\
\hline 2007 & 64 & female \\
\hline 2008 & 66 & female \\
\hline 2008 & 45 & male \\
\hline 2008 & 73 & male \\
\hline 2008 & 61 & female \\
\hline 2008 & 77 & female \\
\hline 2009 & 71 & male \\
\hline 2009 & 53 & male \\
\hline 2009 & 59 & male \\
\hline
\end{tabular}

Time: year of the first surgery

Years: years old of the patients

Table 1: Dates of patients.

\begin{tabular}{|c|c|c|c|c|c|}
\hline Pacient MVD & Fg & Size & Inf. & Mts. & TNM \\
\hline 45 & 2 & 4.5 & no & no & T1N0M0 \\
\hline 31.6 & 2 & 3 & no & yes & T1N0M1 \\
\hline 34.8 & 1 & 2 & no & no & T1N0M0 \\
\hline 25.6 & 2 & 10 & yes & no & T2N0M0 \\
\hline 19 & 4 & 5 & yes & no & T1N0M0 \\
\hline 23.8 & 2 & 13.2 & no & no & T2N1M0 \\
\hline 24.2 & 2 & 8 & yes & no & T3N1M0 \\
\hline 18.2 & 4 & 8 & yes & no & T1N0M0 \\
\hline 53 & 1 & 2.5 & yes & no & T1N0M0 \\
\hline 43.4 & 2 & 6 & no & no & T1N0M0 \\
\hline 43.8 & 2 & 4 & no & no & T1N0M0 \\
\hline 36.8 & 3 & 5 & yes & no & T1N0M0 \\
\hline 24 & 3 & 7 & yes & no & T1N0M0 \\
\hline 31.6 & 2 & 8 & yes & no & T2N0M0 \\
\hline 27 & 2 & 6 & yes & no & T1N0M0 \\
\hline 34 & 3 & 11 & yes & yes & T2N1M1 \\
\hline 27.6 & 1 & 6 & yes & yes & T1N1M1 \\
\hline
\end{tabular}

MVD: Microvessel density

Fg: Fuhrman grade

Size: in $\mathrm{cm}$, corresponding at the maximum diameter of the tumor

Inf: Infiltration of surrounding tissues

Mts: metastasis

Table 2: Descriptive analysis of the samples of the tumour.

\begin{tabular}{|c|c|c|c|c|c|c|c|}
\hline \multicolumn{4}{|c|}{ Mean $^{a}$} & \multicolumn{4}{|c|}{ Median } \\
\hline \multirow{2}{*}{ Estimate } & \multirow{2}{*}{$\begin{array}{l}\text { Std. } \\
\text { Error }\end{array}$} & \multicolumn{2}{|c|}{$\begin{array}{c}95 \% \text { Confidence } \\
\text { Interval }\end{array}$} & \multirow{2}{*}{ Estimate } & \multirow{2}{*}{$\begin{array}{l}\text { Std. } \\
\text { Error }\end{array}$} & \multicolumn{2}{|c|}{$\begin{array}{c}95 \% \text { Confidence } \\
\text { Interval }\end{array}$} \\
\hline & & $\begin{array}{l}\text { Lower } \\
\text { Bound }\end{array}$ & $\begin{array}{l}\text { Upper } \\
\text { Bound }\end{array}$ & & & $\begin{array}{l}\text { Lower } \\
\text { Bound }\end{array}$ & $\begin{array}{l}\text { Upper } \\
\text { Bound }\end{array}$ \\
\hline 5,073 & 0,295 & 4,494 & 5,652 & 6,000 & 0,000 & . & . \\
\hline
\end{tabular}

aEstimation is limited to the largest survival time if it is censored

Table 3: Kaplan Meier survival. Means and Medians for Survival Time.

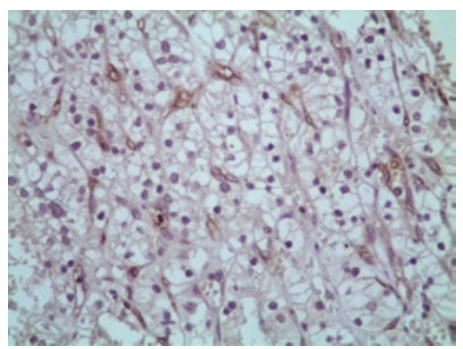

Figure 1: Clear cell RRC. Fuhrman grade 1.

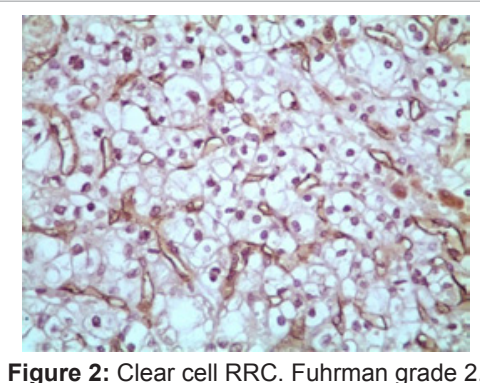

Figure 2: Clear cell RRC. Fuhrman grade 2 .

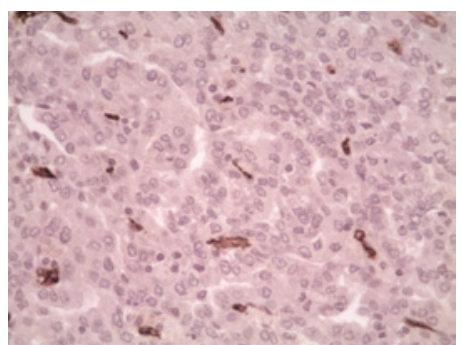

Figure 3: Clear cell CCR. Fuhrman grade 3.

microvessel, as well as tumour cells and other connective tissue elements were considered a single, countable microvessel. Each counting was expressed as the highest number of microvessel identified within $0.06 \mathrm{~mm}^{2}$ fields at a magnification of $100 \mathrm{X}$. Ten fields of the most intense vascularization (hotspots) were analyzed for each tumour.

\section{Statistical analysis}

The CD34 expression was analyzed by Anova and Student Newman Multiple Comparison Test and Tuckey like post test, and the results were expressed as $\mathrm{X} \pm \mathrm{SE}$ of the total of marked vessels in the selected areas for every tumour.

We used Spearman Correlation for studying the correlations between MVD and Fuhrman grade and tumour size, and Kaplan Meier survival analysis for the disease free survival of the patients.

For all statistical analyses, the level of significance was set at less than 0.05 . 


\section{Results and Discussion}

Our results show that there is a negative correlation between the MVD and the Fuhrman nuclear grade, whereas $\mathrm{R}=-0.46$; and $\mathrm{p}<0.05$. On the other hand, there is a positive correlation between the MVD and the maximum tumoral diameter, whereas $\mathrm{R}=0.47$ and $\mathrm{p}<0.05$ (Figure 5).

The follow up of the patients after the laparoscopic surgery was 6 years, since 2006 until 2011, and Kaplan Meier trends showed that the mean of disease free survival was 5 years (Table 3) (Figure 6).

The interest of our study was to compare angiogenesis parameter (MVD) in clear cell RCC versus possible prognostic markers like, Fuhrman degree and tumoral size. In earlier studies, MVD was used as a parameter for angiogenesis in RCC, and evaluated as a possible prognostic marker, in spite of leading to conflicting results $[9,10,15]$.

There is an increasing evidence of the value of nuclear morphometry as a marker of tumour behavior [16,17], and has now been used to predict the prognosis of RCC [18-20].

As we can see in our results, the MVD of clear cell RCC have a negative correlation with the Fuhrman nuclear degree. In accordance with us Rubio-Briones [12] and Baldewjins [15] found that there was an inverse correlation between MVD and Fuhrman grade in the same tumor. These could be due to a relative decrease of vascular dependence of cancer cells, and this is associated with features of increased malignancy $[21,22]$. The tolerance of hypoxic conditions can explain why renal tumours with high-Fuhrman grade can afford an increased

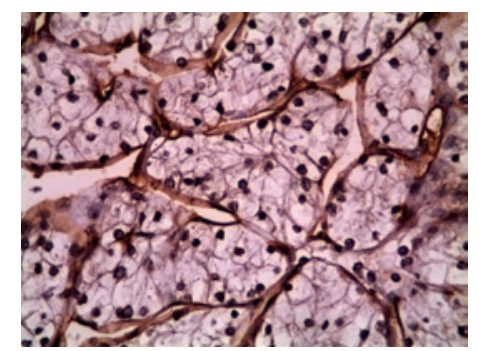

Figure 4: Clear cell CCR, Fuhrman grade 4

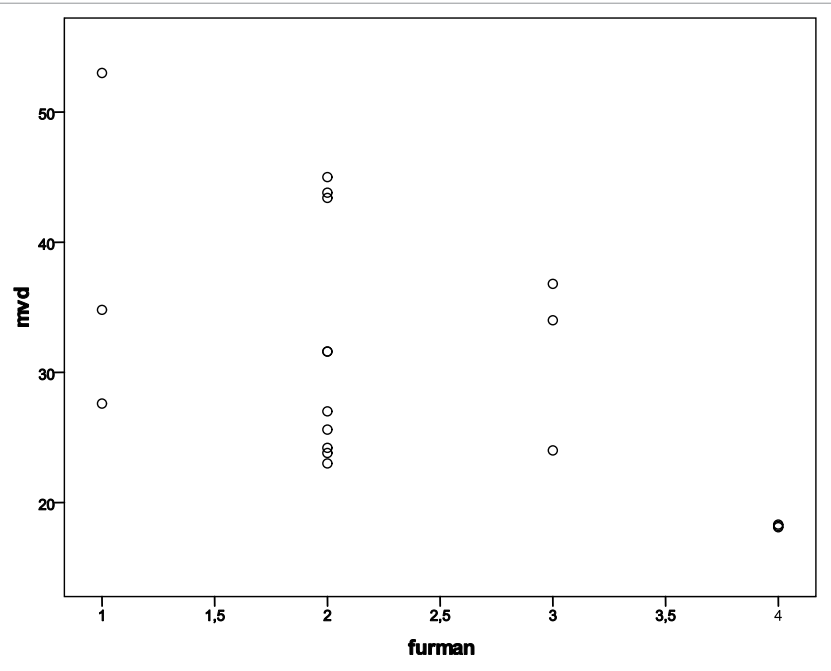

Figure 5: Correlations Spearmant between Furhman grade and MVD.

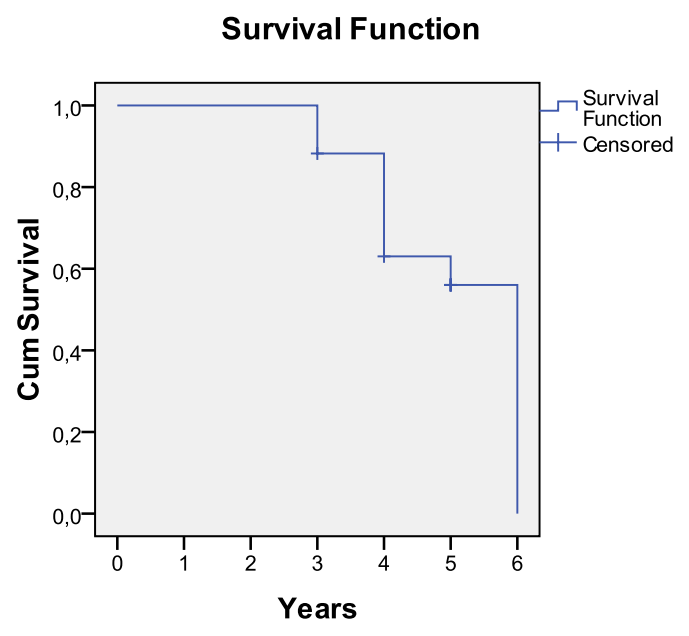

Figure 6: Kaplan Meier survival curve.

intercapillary distance in comparison with low-Fuhrman grade [15]. These differences in angiogenesis biology might have impact on the antiangiogenic treatment effect on clear cell RCC. Moreover Klatte et al. [23] found that Fuhrman grade should be the standard grading system for papillary renal cell carcinoma, because it provides independent prognostic information. On the other hand, Kavantzas et al. [24] found a positive correlation between a high MVD and a high tumoral grade in renal cell carcinoma. This difference with our results may be due to the fact that they used the factor-VIII related antigen as staining for endothelial cells instead of CD34.

In our results we demonstrated a positive correlation between MVD and tumoral size. This may be due to the fact that angiogenesis is an essential process since solid tumours cannot growth beyond 1-2 $\mathrm{mm}$ in diameter without neovascularization [5]. However, we need to mention contradictory previous results, in which other authors found that a high MVD was significantly related to non-metastatic status and smaller size of tumours, but we agree with Yildiz that tumoral size emerge as independent prognostic factor [8,9]. Moreover, Mohseni et al. [11] did not observe any association between angiogenesis and tumor size. Finally, Brookman-May et al. [25] reported that tumour size did not have a significant influence on cancer specific survival in pT2 renal cell carcinomas.

In conclusion, we found that a high MVD is related with a low Fuhrman nuclear grade and a high tumoral size. The possible significance of these results can be that in fact we need more than one parameter to predict the biological behavior of clear cell CCR.

\section{Acknowledgement}

We thank Javiera Marini and Lic. Bárbara Desantolo for the technical assistance and María Eugenia Ghirimoldi and Sara Moyano for the language proofing.

\section{References}

1. Jonasch (2006) Renal cell carcinoma. MD Anderson Manual of Medical Oncology. In: Kantarjian HM, Wolff RA, Koller CA (Eds), New York: McGrawHill.

2. Linehan MW, Berton Z, Bates (2001) Cancer of kidney and ureter. Principles and Practice of Oncology. In: Devita VT Jr, Hellman S, Rosenberg SA (Eds), (6thedn), Philadelphia, Pa: Lippincott Williams \& Wilkins: 1362-1396.

3. Coppin C, Porzsolt F, Awa A, Kumpf J, Coldman A, et al. (2005) Immunotherapy for advances renal cell cancer. Cochrane Database Syst Rev: CD001425. 
Citation: Pablo C, Marcela G, Lía EA, María IA (2012) Correlation between MVD and Two Prognostic Factors: Fuhrman Grade and Tumoral Size, in Clear Cell Renal Cell Carcinoma. J Cancer Sci Ther 4: 313-316. doi:10.4172/1948-5956.1000160

4. Grignon DJ, Che M (2005) Clear cell renal cell carcinoma. Clin Lab Med 25: 305-316.

5. Folkman J, Watson K, Ingiber D, Hanahan D (1981) Induction of angiogenesis during the transition from hyperplasia to neoplasia. Nature 339: 58-61.

6. Vermeulen P, Gasparini G, Fox S, Toi M, Martin L, et al. (1996) Quantification of angiogenesis in solid human tumors: an international consensus on methodology and criteria of evaluation. Eur J Cancer 32A: 2474-2484.

7. MacLennan G, Bostwick D (1995) Microvessel density in renal cell carcinoma: lack of prognostic significance. Urology 46: 27-30.

8. Imao T, Egawa M, Takashima H, Koshida K, Namiki M (2004) Inverse correlation of microvessel density with metastasis and prognosis in renal cell carcinoma. Int J Urol 11: 948-953.

9. Yildiz E, Ayan S, Goze F, Gokce G, Gultekin EY (2008) Relation of microvesse density with microvascular invasion, metastasis and prognosis in renal cell carcinoma. BJU Int 101: 758-764.

10. Minardi D, Lucarini G, Filosa A, Milanese G, Zizzi A, et al. (2008) Prognostic role of tumor necrosis, microvessel density, vascular endotelial growth factor and hipoxia inducible factor-1 alpha in patients with clear cell renal carcinoma after radical nephrectomy in a long term follow-up. Int $\mathrm{J}$ Immunopathol Pharmacol 21: $447-455$

11. Mohseni MG, Mohammadi A, Heshmat AS, Kosari F, Meysamie AP (2010) The lack of correlation between mast cells and microvessel density with pathologic feature of renal cell carcinoma. Int Urol Nephrol 42: 109-112.

12. Rubio-Briones J, Calatrava A, Fenandez-Serra A, Ramos Ruiz R, Iborra I, et al. (2011) [Immunohistochemical expression of microvascular density and carbonic anhidrase IX in renal carcinoma. Relation to histological type and tumoral progression]. Actas Urol Esp 35: 80-86.

13. Eble JN, Sauter G, Epstein JI, Sesterhenn IA (2004) Pathology and genetics tumours of the urinary system and male genital organs. World Health Organization Classification of tumours.

14. Weidner N, Semple J, Welch WR, Folkman J (1991) Tumor angiogenesis and metastasis correlation and invasive breast carcinoma. N Engl J Med 324: 1-8.

15. Baldewjins MM, Thijssen VL, Van den Eynden GG, Van Laere SJ, Bluekens AM, et al. (2007) High-grade clear cell renal cell carcinoma has a higher angiogenic activity than low-grade renal cell carcinoma based on histomorphologica quantification and qRT-PCR mRNA expression profile. Br J Cancer 96: 18881895.

16. Francois C, Decaestecker C, Petein M, van Ham P, Peltier A, et al. (1997) Classification strategies for the grading of renal cell carcinomas, based on nuclear morphometry and densitometry. J Pathol 183: 141-150.

17. Paraskevakou E, Kavantzas N, Pavlopoulos PM, Delibasis A, Yova D, et al (1996) Computerized nuclear morphometry of renal cell carcinomas. Gen Diagn Pathol 142: 101-104.

18. Carducci MA, Piantadosi S, Pound CR, Epstein JI, Simons JW, et al. (1999) Nuclear morphometry adds significant prognostic information to stage and grade for renal cell carcinoma. Urology 53: 44-49.

19. Fujikawa K, Sasaki M, Aoyama T, Itoh T (1997) Role of volume-weighted mean nuclear volume for predicting disease outcome in patients with renal cell carcinoma. J Urol 157: 1237-1241.

20. Monge JM, Val-Bernal JF, Buelta L, Garcia-Castrillo L, Asensio L (1999) Selective nuclear morphometry as a prognostic factor of survival in renal cell carcinoma. Histol Histopathol 14: 119-123.

21. Carmeliet P, Dor Y, Herbert JM, Fukumura D, Brusselmans K, et al. (1998) Role of HIF-1alpha in hypoxia-mediated apoptosis, cell proliferation and tumour angiogenesis. Nature 394: 485-490.

22. Yu JL, Rak JW, Carmeliet $P$, Nagy A, Kerbel RS, et al. (2001) Heterogeneous vascular dependence of tumour cell populations. Am J Pathol 158: 1325-1334.

23. Klatte T, Anterasian C, Said JW, de Martino M, Kabbinavar FF, et al. (2010) Fuhrman grade provides higher prognostic accuracy than nucleolar grade for papillary renal cell carcinoma. J Urol 183: 2143-2147.

24. Kavantzas N, Paraskevakou H, Tseleni-Balafouta S, Aroni K, Athanassiades $\mathrm{P}$ et al. (2007) Association between microvessel density and histologic grade in renal cell carcinomas. Pathol Oncol Res 13: 145-148.

25. Brookman-May S, May M, Zigeuner R, Shariat S, Scherr D, et al. (2011) Collecting system invasion and Fuhrman grade but not tumor size facilitates prognostic stratification of patients with pT2 renal cell carcinoma. J Urol 186 2175-2181. 